\title{
Keeping Up
}

\author{
Herbert Williams, Compiler
}

\section{Haley Collection at ASU}

Professors Larry and Janet Barr, of the Department of Library and Media Studies at Appalachian State University, report that Gail E. Haley, writer and illustrator of children's picture books and writer-in-residence in the Department of Library and Media Studies at Appalachian State University, has collected materials that now form an important resource concerned with the history and culture of childhood. She has made this collection available on permanent loan.

The collection includes chapbooks that offer glimpses into the materials available to juvenile readers in the eighteenth and nineteenth centuries. Among the many interesting ones are The Story of the Three Bears and The $F_{0 x}$ and the Geese, published about 1860 with engravings by Kate Greenaway's father, John. Also included are toys, such as toy lead soldiers, and more than 130 board games and card games, dating from about 1800 . The earliest of the board games dates back to the 1650's. Also included are dolls, juvenile periodicals, mechanical toys, game sheets, and children's books. In addition, various publications from almanacs to zoology books are represented.

When the collection is organized, it will become a major component of the Appalachian Cultural Center. Plans for use of the collection include support for courses taught in the sourtment of Library and Media Studies, a for for travelling exhibits, and as a resource prod arch interests in the technical aspects of Theducing modern picture books for children. Gail collection also includes correspondence of incl Haley with publishers of her own works, A St the Caldecott Medal winner, A Story, the Story; and Post Office Cat, which won both and Kate Greenaway Medal in Great Britain the the Kadai Tosho prize in Japan, as well as notart work for her other books, including the Man Go Away, Stay Away, and The Green collection nearly ten thousand items in the lection are a strong resource for the study of the culture of childhood in Western society during the past three hundred years.

\section{Oral History Project at Shaw University}

Much history would be lost to the researcher and serious student if it were not for the oral history. Few Blacks write t1 eir memoirs or keep diaries. The oral tradition is not new to them. Family and tribal histories as well as folk tales have been told and handed down from generation to generation.

Shaw University is the oldest historically Black institution of higher learning in both the State of North Carolina and the South and the fourth oldest in the nation. Founded in the capital city of North Carolina, Raleigh, in late 1865 , Shaw was the first step toward establishing North Carolina as a center of Black higher education. With five public and six private colleges and universities enrolling over 24,000 students, the state today can lay claim to the most substantial number of Black institutions of higher education in the nation.

Shaw's founder, Henry Tupper of Monson, Massachusetts, came to Raleigh in October 1865 , as a missionary for the American Baptist Home Mission Society. A graduate of Amherst College and Andover Theological Seminary, he had served in the Union Army and returned to bring the gospel to the freedmen. Tupper quickly realized that Blacks in the South needed education, and began his teaching activities primarily to train Black clergy. On December 1, 1865, he instituted his first theology class in a downtown Raleigh hotel room. This class and date mark the real beginning of Shaw University, and within a short period of time Mrs. Tupper was teaching young women in her home.

Besides the undergraduate and divinity schools, Shaw University included School of Medicine (1881), Law (1886), and Pharmacy (1891). The University thus pioneered in professional training for Blacks and was one of the few institutions in the South offering such 
needed service and leadership to Blacks throughout the country. In North Carolina, Shaw Alumni played a particularly vital role in the founding and development of the public Black colleges and universities. The founder and first president of North Carolina Central University at Durham, Dr. James E. Shepard of Raleigh was an alumnus of Shaw as well as other pioneer presidents of North Carolina A\&T State University of Greensboro, Elizabeth City State University and Fayetteville State University. North Carolina A \& T State University at Greensboro acknowledges its founding as a satellite of Shaw University.

During World War I the Law, Pharmacy, and Medical Schools were closed. The institution continued, however, to play an important role in education and in the greater community through its undergraduate and theology programs.

Because Shaw University is under the auspices of the Baptist Church we will include a history of the General Baptist State Convention of North Carolina and prominent Biack theologians who have been affiliated with the University. All of these are resources to be drawn on for the project.

For further information relative to the Oral History Project and the University Archives, of which the Project is a part, please contact:

Clarence Toomer, Director, Library/Learning Resources Center, Shaw University, Raleigh, North Carolina 27611, Phone: (919) 755-4930; or, Ms. Ramona Jones, Media Librarian, Library/Learning Resources Center, Shaw University, Raleigh, North Carolina 27611, Phone: (919) 755-2911.

\section{UNC-G Announces Wilson Scholarships}

The Department of Library Science/Educational Technology at UNC-Greensboro has announced the criteria for two $\mathrm{H}$. W. Wilson Scholarships of $\$ 1,500$ each for the fall of 1983 . Applicants may be residents or non-residents of North Carolina, interested in any type of library, and not presently enrolled in the program. Other criteria:

1. Applicants must unconditionally meet all existing LS/ET Admissions requirements.

2. Applicants must have a GPA of at least 3.0 in all previously taken academic work.

3. Applicants must submit three letters of reference from individuals familiar with applicant's current activities, career goals, aptitude for and interest in librarianship, and potential for professional growth.
4. Applicants must submit a summary statement of financial need.

5. Applicants must submit a brief essay meeting the following criteria:

a. The essay should be typed, double-spaced, and not to exceed 1500 words.

b. The essay should discuss:

(1) Why the applicant is interested in the Library Science/Educational Technology profession.

(2) What specific goals the applicant hopes to pursue in the LS/ET program.

Essays will be judged on the applicant's ability to communicate, in written form. the preceding factors. This essay is separate from any documentation submitted for regular admission to the program.

Address all inquiries to Dr. Alan Samuels, Chair Admissions Committee, Department of Library Science/Educational Technology, McNutt Bldg., UNC-G, Greensboro, N.C. 27412. The deadline is April 15, 1983.

\section{Thirty-six Year History of The North Carolina Catholic on Microfilm}

Responding to requests by the University of Notre Dame which considered the newspaper vital to the teaching and research needs of the Roman Catholic Church, and by the University of North Carolina, Chapel Hill which views the paper as an important part of the holdings in their North Carolina collection the Board of Directors of The North Carolina Catholic ap. proved funding for this microfilm project.

The newspaper, filmed by the Microfilming Corporation of America, covers the entire thirty-six year history of the paper from October 6, 1946 thru September 26, 1982. Future issues will become available on a bi-yearly basis.

Both silver positive copies and vesicular positive copies are available immediately from the Business Manager of The North Carolina Catholic, 300 Cardinal Gibbons Drive, Raleigh N.C. 27606 . The cost for the complete nine reel silver copies is $\$ 360$; vesicular copies are $\$ 288$.

The newspaper was founded to serve the Roman Catholics in North Carolina and con. tinues to do so now that the State is divided into the Diocese of Charlotte and the Diocese of Raleigh. The paper is a weekly publication of tabloid size normally twelve pages in length Current circulation numbers 25,000 . 


\section{LSCA Oral History Project Done By UNC-CH Library School}

The School of Library Science, UNC-CH, has completed an oral history project on the twenty-five year history of the Library Services and Construction Act. Conducted undera grant of $\$ 9,944$ from the U. S. Department of Education, Dean Edward G. Holley and Robert F. Schremser, doctoral student at UNC, interviewed thirteen persons who were major participants in the initial passage of the Act in 1956 and its expansion and extension in subsequent years.

The LSCA Oral History Project has produced two useful works: five video tapes of approximately 260 minutes and the manuscript of a book, "The Library Services and Construction Act: An Historical Overview from the Viewpoint of Major Participants," which will be published by JAI Press in the late spring, 1983. Readers have described the manuscript as "a fascinating account of the process of moving from an idea, to a legislative program for an organization, to a law as complex as LSCA is today," and as a story "where the drama comes through." Viewers of the video tapes have been similarly enthusiastic about the discussions by the panelists.

In addition to the video tapes, UNC-CH has collected other materials both in printed form and on audio tapes, which will be useful for researchers working on topics related to federal library legislation. Two persons interviewed on audio tapes were Julia Bennett Armistead, ALA Washington Office Director when the Library Services Act was passed in 1956, and Mary Allen Jolley, Administrative Assistant to Congressman Elliott and to the National Advisory Committee on Libraries in 1966-68. Holley and Schremser expect to interview additional persons in subsequent years and the School of Library Science will continue to collect materials related to the Library Services and Construction Act. The video tapes are available for loan from the ALA Headquarters Library and also for loan or for purchase from the School of Library Science. The book, with many quotations from the interviews and an extensive bibliography, will be available from JAI Press. Materials collected for this project will be made available to qualified researchers upon application to the Dean of the School of Library Science.

\section{Microcomputer Help From the Educational Media Division}

Media Matters for November 1982 helpfully lists some resource persons at the Division of Educational Media, N.C. Dept. of Public Instruction who can offer help at the state level to media professionals. They are:

Vergie Cox, Chief Consultant of the MRE Center, is responsible for microcomputer courseware review, evaluation, selection and publication of Advisory Lists. MRE has workshops on courseware evaluation, selection and utilization and is developing a microcomputer resources and educational data base file. (919. 733-3929)

Johnny Shaver, Chief Consultant of Media Support, is responsible for microcomputer hardware evaluation and selection as well as workshops on selection of equipment and the various administrative and management applications available for microcomputers. (919-733-4008)

Carol Lewis, Chief Consultant of School Media Programs, leads the regional media consultants in the development of workshops to assist school media personnel in the management and use of microcomputers hardware and courseware in the school media program. They plan to develop microcomputer a wareness and literacy workshops to demonstrate ways to correlate this area of the media skills program with K-12 content areas. (919-733-3193)

Bill Pendergraft, Chief Consultant ITV, is responsible for evaluation, selection, and either acquisition or production of staff development instructional courseware programs for open-air broadcast. (919-733-3193)

Mary Holloway, Special Assistant for Educational Media, is working to develop microcomputer awareness and literacy workshops for the Department professional and clerical personnel. She will coordinate current uses in the Support Services Area and be familiar with various management applications. (919-7333193)

Elsie Brumback, Deputy Assistant Superintendent, provides overall coordination and direction of the microcomputer program throughout the Agency and State. (919-7333193)

\section{New Book On School Censorship}

Dr. Joseph E. Bryson, professor of education at the University of North Carolina at 
Greensboro, is the co-author of a recently published book on the problem of censorship of library and instructional materials in the public schools. Co-authored with Dr. Elizabeth W. Detty, The Legal Aspects of Censorship of Public School Library and Instructional Materials, is published by the Michie Company, Charlottesville, Virginia.

The book emerged from Dr. Detty's dissertation, completed in 1981 for her doctor of education degree at UNC-Greensboro. Dr. Detty is presently the director of instruction and personnel for the Salisbury City Schools. The book provides school administrators and school board members with legal, philosophical, and practical guidelines in dealing with censorship problems, which have become more controversial during the last twenty years.

\section{SOLINET Users' Group to Hear Charles Hildreth}

Charles Hildreth, author of Online Public Access Catalogs: the User Interface (Columbus, Ohio: OCLC, 1982), will be the featured speaker at the spring meeting of the North Carolina SOLINET Users' Group. Mr. Hildreth will discuss the research that resulted in the analysis of ten online catalogs with particular emphasis on how users approach an online catalog, what they want from the catalog, and how the catalog responds to them. Mr. Hildreth's presentation will be followed by a panel representing three types of online catalogs: Dawn Lamade, SOLINET, LAMBDA; Jeanne Sawyer, UNC, Triangle Research Libraries Network; and Ashby Wilson, Greensboro Public Library, Dataphase.

The meeting will be held at Duke University May 5, 1983, with registration at 9:00 and the first session beginning at 9:30. Registration fee for the meeting is $\$ 5.00$. A buffet lunch will be available at additional cost.

For more information about the program and how to register, contact the coordinator, Janie Morris, Perkins Library, Duke University, Durham, N.C., 27706, phone (919) 684-6539.

\section{Adversary Hearing Salvaged}

The Legislative Research Commission on Obscenity Laws held its last meeting on November 12, 1982 in the Legislative Building in Raleigh. For the past year the Commission has been studying the state's obscenity laws in order to make recommendations to the 1983 General Assembly concerning any changes. They have heard testimony from various groups and individuals speaking on concerns.

The chairman of the NCLA Intellectual Freedom Committee was appointed by Speaker of the House Liston Ramsey as the librarian designee on the panel. NCLA has taken a stand in opposition to repeal of the prior adversary hearing to prevent undue harassment or punitive action by would-be censors. State statutes now provide for a judicial decision in obscenity cases prior to prosecution. Without

\section{Harlan Craig Brown 1906-1982}

Harlan Brown who died October 10,1982 will be missed by his many friends in the North Carolina Library Association. A long-time and devoted member, he served as President in 1949-50, as a member of numerous committees, and as NCLA's representative to the Council of the American Library Association.

His home base was Raleigh where he was on the staff of the D. H. Hill Library at N. C. State University for 35 years. As Director for 25 years, he emphasized especially friendly, helpful service and strong research collections. Under his leadership, the Library grew from a small college library of 50,000 volumes to a major university facility with 500,000 volumes. He retired from N.C. State in 1971 but the D. H. Hill Library and its spirit of public service remains as a living tribute to his devotion and efforts.

In recognition of his contributions, Honorary Membership was conferred on him by NCLA in 1977. Harlan Brown had many interests and a host of friends, both inside and outside librarianship. We celebrate his life; his warm friendship, his cheerful outlook, and most of all, his unusually deep concern for people, books and libraries.

I. T. Littleton 
the adversary hearing, a local police official would make the obscenity determination, prosecution would follow before any type of judicial decision occurred.

Former Senator John Cavanagh, R-Forsyth, led the forces in favor of repealing the hearing while IFC Chair Gene D. Lanier spoke in opposition. A resolution in support of the hearing approved by the NCLA Executive Board and endorsed by over 25 other professional groups across the state was presented to the Commission. After a lengthy discussion, a vote was taken which resulted in a 6-6 deadlock and thus the motion to repeal was defeated.

Voting for abolishing the hearing were Cavanagh; former Senator James McDuffie, DMecklenburg; Wake County District Attorney J. Randolph Riley; Representative Jo Graham Foster, D-Mecklenburg; and District Judge Robert Leatherwood of Bryson City. The opponents included Lanier; Representative Bertha Holt, D-Alamance; Robert Emanuel, representing the magazine distributors; Rich Gunter of the Asheville Citizen-Times; and Sandy Jordan, representing the theater owners. Not present for the vote were Edwin Speas of the Department of Justice and Carl Venters, Jr., representing the television industry.

Representative George Miller, D-Durham, and Senator Robert Warren, D-Johnston, at first exercised their option as commission cochairmen by not voting. But with the group yes.

Librarians on hand for the all-day session included representatives from Charlotte, Yarham, Goldsboro, Greensboro, Tarboro, and anceyville.

\section{New Appointments at Duke and \\ UNC-Chapel Hill}

Ailliam Treat has been appointed the new Asistant Librarian for Administrative tivervices at the Duke University Library, effecKent May 1, 1983. Receiving his M.L.S. from a cht State, he has worked for fourteen years as was puter programmer for the Air Force, and Sers most recently Director of Technical Ohio. At Duke, Helen I. Reed was a ppointed Head of the Acquisitions Department at the Duke

University Library, effective December 6, 1982.

Ver came to Duke from the Northwestern Uni-

versity Library, where she was the assistant head of acquisitions and assistant order librarian. Before that, she worked at the Cornell University Libraries in the Automated Systems Control Group. She received her M.L.S. at the University of Michigan.

Rebecca W. Davidson has been appointed Head, Bibliographic Searching Section in the Acquisitions Department at the University of North Carolina at Chapel Hill, effective October 16, 1982. Receiving her M.S.L.S. at UNCChapel Hill in 1975, she has worked at Western Carolina University, the National Library of Medicine, and the Health Sciences Library at UNC-Chapel Hill. She replaces Janet Flowers, who became Head of the Acquisitions Department at UNC-Chapel Hill in July 1982.

\section{Reynolds Grant for COM Catalog}

A computer-produced microfiche catalog of the libraries of three Triangle-area universities will soon be available thraughout North Carolina. Production and distribution of the COM (Computer-Output-Microfiche) catalog is being supported by a $\$ 22,500$-grant from the Z. Smith Reynolds Foundation of Winston-Salem to the UNC-Chapel Hill Library.

According to Dr. James Govan, UNC-CH Librarian, "this development will enable scholars, businessmen, students, and others seeking information to have much more rapid access to our library holdings, as well as those of Duke and N.C. State Universities. It will be a boon to library users across the state."

Copies of the catalog will be located in the main libraries and branches of the three universities, in organizations in the Research Triangle Park, in all the libraries of the University of North Carolina system, and in major public and other academic libraries in North Carolina.

Each copy of the COM catalog will contain 431 microfiche, which will list recent acquisitions of the three libraries, generally since 1975, totalling almost two million volumes. Previously, such information was available only by personal visits to the libraries or by telephone.

The microfiche catalog is an interim stage in computerization of library information. Eventually, through a joint project among the three Triangle libraries, their catalogs will be accessible via on-line terminals linked to computers in each library. "This COM catalog is a by-product of that project," said Govan, "but it and future fiche catalogs will function as backups to the on-line catalog. They also will continue to serve personal users and organizations 
which cannot afford the costs of computer terminals and communications line costs. We could not have made this catalog available to the State without the Reynolds grant."

\section{New Book for Elementary and Middle Schools}

Literature Puzzles for Elementary and Middle Schools (Libraries Unlimited) by Carol Veitch and Cecilia Boklage is now available. The book is designed to supplement literature programs and offer enrichment activities in the form of seek-a-word and crossword puzzles for twenty-five popular children's books.

By referring to various characters and incidents in the books, the contents is designed to either pique students' interest in reading a particular title or to help them recall the story line. Suggestions are given for using the puzzles in the classroom or media center. Indexes of recommended grade levels by puzzle title, along with puzzles by recommended grade level, assist the user in selecting the appropriate puzzles and books for the individual student or class.

Dr. Veitch is a faculty member in the ECU Department of Library Science and specializes in courses covering materials for children and young adults. Ms. Boklage, Pitt Community College librarian, has varied experiences in different types of libraries.

\section{Grace Farrior Retires}

Grace Betts Farrior, Head Acquisitions Librarian at the University of North Carolina at Greensboro and past President of the North Carolina Chapter of SLA, retired from university service on March 1, 1983. Mrs. Farrior, who is a Meredith College alumna and a graduate of the library school at the University of North Carolina at Chapel Hill, was an assistant to William Pullen in the Documents Department at UNC-Chapel Hill before joining the library staff at UNC-Greensboro in 1957. She has held several important administrative positions in Jackson Library at UNC-G: Assistant Circulation Librarian, Administrative Assistant Librarian, Assistant Librarian, Head Acquisitions Librarian. Mrs. Farrior has been instrumental in the growth of Jackson Library from an undergraduate library serving 3,000 undergraduate women to a modern research library serving the needs of over 10,000 students, $30 \%$ of whom are graduate students, and 700 faculty. Indeed, her contri- butions to the general development of her university through her faculty assignments and committee work, in addition to her work in the library, have been exemplary and noteworthy over the past quarter of a century.

Mrs. Farrior has been equally dedicated to her profession. Elected to Beta Phi Mu in 1958, she has held various offices in the organization, including President of the Epsilon Chapter of North Carolina. She has also served on the Research Committee of Delta Kappa Gamma and as the Chairman of the Nominating Committee. She has been very active in SELA. serving on the editorial board of the Southeastern Librarian as North Carolina Reporter from 1960 to 1973 . She has held membership on a number of committees of NCLA and has chaired NCLA's Honorary Membership Com. mittee, Scholarship Committee, Recruiting Committee, Displays and Exhibits Committee, and National Library Week Committee. A member of ALA for many years, she has served on its Library Recruitment, Membership, National Library Week, and Automation Committees. She has also held the offices of Secretary-Treasurer of the UNC-G Chapter of AAUP, President of the UNC-Chapel Hill School of Library Science Alumni Association and editor of its Alumni Bulletin, and President of the Meredith College Alumni Chapter in Greensboro. All of this, in addition to her work as Vice President, President, and Past President of the North Carolina Chapter of SLA, has resulted in an extremely rich, active, and fruit ful career for Mrs. Farrior.

James H. Thompson

\section{4th Southeastern Conference on Bibliographic Instruction}

"Library Instruction and the New Tech. nology" is the theme of the 4th Southeaster" Conference on Bibliographic Instruction to be held at the University of North Carolina at Charlotte, June 2 and 3, 1983. This conference, coordinated by the J. Murrey Atkins Library, UNCC, was formerly hosted by the College of Charleston. A dinner with keynote speaker Sharon A. Hogan, Deputy Director, Temple University, is scheduled for the evening of June 2. The day of June 3 will feature several speakers who will address various issues related to the integration of microcomputers. database searching, video technology, and library instruction. Registration deadline is May 1, 1983. For further information contact Edward H. Teague, Reference Unit Head, 
Murrey Atkins Library, the University of North Carolina at Charlotte, Charlotte, N. C., 28223.

\section{EPA Contract at UNC-CH}

Dean Edward G. Holley announced that the School of Library Science UNC-CH has completed negotiations for a new contract for library services with the Environmental Protection Agency, Research Triangle Park, NC. The contract for $1982-83$ provides for the employment of 11 library science students from the master's and doctoral program for twenty hours per-week at a rate of $\$ 6,300$ for the twelve-month period. Students in the master's program must have completed the twelve-hour asic Block before they can be selected for the program. Included in the services provided for the EPA Library are acquisitions, circulation, serials handling, interlibrary loans, reference and referral assistance, data base searching, and maintenance of the Air Information Center. Faculty supervision will be provided by Holley and other members of the faculty.

\section{Neenan at UNC-CH}

Peter Anthony Neenan has joined the faculty of the School of Library Science, UNC$\mathrm{CH}$, as Assistant Professor of Library Science. theenan comes to Chapel Hill from the faculty of tion Graduate School of Library and Informacourseience, Simmons College. He will teach librses in reference, library services, and public on "A. In 1982 he completed his dissertation si "Advocacy and Practitioner Profesians' Dism: An Investigation of Public Librarmatisposition Toward Social Change Inforual Advocacy in Relation to Their IndividWiscofessionalism" at the University of interensin-Madison. His major research affects include the professionalism as it adequate role of librarians in advocating public.

of Dr. Neenan was a lecturer at the University and the Ungton, Northern Illinois University, was the University of Iowa. From 1972-74 he Wenserence/Information and Referral Metror Librarian in the Jackson (Mississippi) B.A. A politan Library System. Neenan holds a M.A. degree from Creighton University and an I $\mathrm{A}$. in Library Science from the University of

\section{Durham County Library Receives Fiche Newspaper Files}

The Durham County Library expanded its Durham and North Carolina collections by purchasing news clippings recorded on microfiche from the Durham Morning Herald and the Durham Sun. The first shipment contains 1,620 microfiche that represent 60,000 newspaper articles dating from 1976. The newspapers' library is producing the fiche. This microfiche collection is the first of its kind to be offered to the public by a newspaper library in North Carolina. The Durham County Library has also acquired the Herald-Sun's Newspaper Library's 1982 computer-produced subject authority file, a guide to the approximately 30,000 clipping files on subjects maintained by that newspaper library.

\section{Lanier Receives Douglas Award}

In Winston-Salem during the first week in November 1982, the North Carolina Association of School Librarians at their biennial conference presented the Mary Peacock Douglas Award to Gene D. Lanier, professor of library science at East Carolina University. Established in 1968 with Mrs. Douglas being the first recipient, the award recognizes outstanding contributions to North Carolina school libraries. Mrs. Douglas, who died in 1970, was North Carolina's first school library supervisor with the Department of Public Instruction and attained an international reputation for her efforts in school library development.

Lanier, in receiving the coveted award was cited for "serving in every capacity in the committee structure of NCASL, for his active and highly visible leadership including serving as president of the North Carolina Library Association, his dedicated commitment to the revision of standards for school library media programs, and his vigorous pursuit of quality education for school librarians."

\section{Shearer Presents Paper}

Kenneth Shearer, Professor, School of Library Science, NCCU, and editor of Public Libraries, presented a paper at the Fifth National Conference on the Third World in Omaha, Nebraska on Thursday, October 28, 1982. The paper, entitled, "How Much Intellectual Capital is Banked in the Principal Human Languages?" deals with languages in terms of 


\section{Margaret Johnston}

Margaret Johnston, former director of the Stanly County Public Library, died in Albemarle on December 27, 1982. Known as one of the outstanding public librarians in the state, she became the first director of the newly established Rutherford County library. She has been library director in Cumberland, Haywood, Rockingham, and Stanly counties. During her 15 years in Haywood County, she led the public library there in one of its finest periods of progress. During her 17-year tenure in Stanly County she promoted the construction of a new main library building in Albemarle, as well as new buildings in Norwood and South Albemarle. In addition, she developed numerous educational and cultural programs for patrons. She retired as director of the Stanly County Public Library on June 30, 1976. Margaret Johnston's work was recognized by NCLA, in which she served for many years as both an officer and a member of key committees. Memorial contributions may be made to the Stanly County Public Library, to be used for the Margaret Johnston Heritage Room.

the amount and kinds of publications produced in each and the relation of these linguistic characteristics to the opportunities available to the readers of various languages.

After Chinese, English is the most widely spoken language. Together they are spoken by one quarter of the people on the planet. Books (excluding textbooks) for children are produced in only a few languages. Public and school libraries as we know them in the Englishspeaking world therefore, are unattainable now for most of the world's children. Shearer deals with this and other differences in the adequacy of text-dependent enterprises in various languages based on the analysis of data published by the United Nations Educational, Scientific and Cultural Organization.

\section{Day Care Library}

Of potential interest to all librarians is a library situated on the fifth floor of an office building in Chapel Hill devoted to materials and resources on day care providers and trainers. This library, the Day Care Technical Assistance and Training System Library, has over 1500 books and 230 audiovisual items. Eligible borrowers include any North Carolina residents who are involved in child care. These borrowers include center-based day care personnel, County Day Care Coordinators, students, teachers, and state agency personnel. Items are mailed to borrowers through the U.S. Postal Service or the state courier service. For their part, borrowers may keep items for four weeks, but are responsible for return postage and insuring audiovisual items. Potential borrowers may contact the library directly by telephone or letter, or they may contact the county Day Care Coordinators in the Depart- ment of Social Services field staff. Those living in the Chapel Hill area are welcome to come by the library when the librarian is on duty. Librarian Holly Willett may be reached Monday through Thursday, 8:30 A.M. to 12:00 Noon at (919) 962-2001, Ext. 233. The address of the library is DC/TATS Library, Frank Porter Graham C D C, 500 NCNB Plaza, Chapel Hill, NC 27514.

\section{Editorial Board Emeriti Notes}

We were pleased to learn that Bill Schenck, our former advertising manager here at North Carolina Libraries from 1979-1982, is the new advertising manager for Information Tech nology and Libraries, beginning with the $198^{3}$ volume. Formerly Head of the Acquisitions Department at the University oi North Carolina at Chapel Hill, Bill is presently collection develop. ment librarian at the University of Oregon.

There's both good news and bad news from Cate Howard, former Children's Services Section Editor who worked at the Wake County Public Libraries. Cate is busily working on het Ph.D. in Library Science at Indiana University at Bloomington, Indiana, but she has had diabetes and is now legally blind. If you would like to write to keep in touch with her, use ? black felt-tipped pen and white paper. $\mathrm{Her}^{\mathrm{r}}$ mailing address is Cate Howard, 3209 E. 10 th Street, Apt. 27-D, Bloomington, IN 47401.

Finally, we're looking forward to seeing another of our former editorial board in print again in these pages when Suzanne Levy will be contributing an article on cooperation between archivists and librarians in a specia section of the Fall 1983 issue of North Carolin ${ }^{\circ}$ Libraries. Suzanne, a former Book Review Editor of $N C L$, is now Curator of the Virginis 


\section{Keeping Up}

Room, Fairfax County Library, Fairfax, Virginia.

\section{Consultants File}

The Consultation Committee of the North Carolina Chapter of SLA is compiling a consultants file of information about members who will do consulting for a fee. The file will be available to companies or individuals who would like consulting work done that is beyond the capabilities of the Consultation Committee. The file will be updated by participants submitting updated forms. For information, write: Consultation Committee, N. C. ChapterSpecial Libraries Association, c/o Darlene Ball, P. O. Box 20288, Greensboro, North Carolina 27420 .

\section{NCCU Advisory Council Make Annual
Visit}

Advisory Council members of the School of Library Science at North Carolina Central University made their annual visit on October 18, 1982. The six members present were: Nancy Doyle Bolt, an independent consultant and President-Elect of the Public Libraries Association (ALA); E. J. Josey, Chief, Division of Specialist Services, New York State Education Librtment; Myrtle McNeill, Director of Moories, Durham City Schools; Elizabeth Soore, an information broker; Toni Patterson, Special Assistant for Quality Assurance ProDram Coordination, North Carolina State Spartment of Public Instruction; and Joshua Libr, President of Maxima Corporation and of brary Resources Corporation of America.

Smith spoke to the students about accountintrity in industry. A luncheon followed with stuductions of the Council members and had ants. Council and Faculty members then ing a session, with Faculty members describ-

Repoir activities not included in the Dean's pred to the Alumni. Accountability was the and ominant theme of the day. Mrs. Patterson to $\mathrm{Mrs}$. McNeill described the State's progress

Progra developing a Quality Assurance

Bolt explor public school personnel, and Mrs.

promed expined the Public Library Association's sharion of output measurement. After announced a list of research ideas Dr. Josey to the School.

\section{ALA Legislative Day April 19}

On Tuesday, April 19, the ninth annual Library Legislative Day will be held in Washington, D.C. during National Library Week. Sponsored by ALA and the D.C. Library Association, Legislative Day is designed to bring library suporters to Washington to lobby Congress on behalf of library programs and funding. Legislative Day begins with delegates being briefed on the current status of federal library legislation, followed by the delegates visiting members of Congress.

Arrangements for the trip will be made by NCLA Governmental Relations Committee Chair Louise Boone. Other NCLA officers and section representatives planning to attend are Mertys Bell, Paula Short, Eugene Huguelet. Also, Dean Annette Phinazee will attend, along with a group of her N.C. Central University Library School students.

\section{Annual Library Trustee and Librarian Conference}

Those attending the 16th Annual Library Trustee and Librarian Conference on June 1-2 will see and hear much of the Workshop in Library Leadership originally held in Minneapolis, Minnesota in 1982 by the American Library Trustee Association. This workshop is being re-done in a number of states besides North Carolina. The purpose of this workshop is to offer library trustees the chance to learn more about their responsibilities as public officials, most of the topics to be discussed being the same as those suggested by librarians and trustees in their evaluations of previous NC Trustees Conferences. Topics will include public awareness, policy making, legislation, advocacy, technology, board orientation and effective meetings. Nancy Stiegemeyer and Virginia Young, ALTA WILL Leaders, will make presentations and conduct small workshop sessions; and Dr. Benjamin Speller, Jr. of the School of Library Science, N.C. Central University, will speak on "Planning For Technology." This 1983 conference will be a practical learning experience for trustees and an opportunity to exchange ideas with some of the highly regarded leaders in trusteeship today.

\section{Workshop/Tour in Children's Literature}

Appalachian State University in cooperation with Newport College-Salve Regina is sponsoring a unique program in children's literature June 25-July 9, 1983. 
The program will include a study of literary/historical sites and related books, visits to the homes of New England writers and artists, lectures and discussions by distinguished writers, field trips and recreational activities in and around Newport, Rhode Island, Connecticut, Massachusetts, and New York. Participants in the program will be housed on the campus of Newport College, Newport, Rhode Island. Newport, located at the southern tip of Narragansett Bay, was founded in 1639. During the 18th century the city thrived as a major colonial seaport and as the seat of government for the Colony of Rhode Island and Providence Plantation. During the 19 th century the small coastal city became a summer mecca for the newly rich of America and the palatial mansions of this area are a major attraction.

Participants enrolled in the workshop/tour will receive four hours of credit in the Department of History at Appalachian State University.

If you are interested in two weeks of children's literature in Newport as well as exciting literary experiences en route, contact: Ms Beulah Campbell or Dr. Ruby Lanier, Department of History, Appalachian State University, Boone, North Carolina 28608.

\section{Hardison and Adams Honored}

The North Carolina Public Library Directors Association held its annual meeting at the New Hanover County Library November 18-19. The Program included a presentation by Dr. Judith Ruderman of Duke University's Office of Continuing Education on "Reaching New Audiences with Independent Scholars: Humanities Programs in Our Public Libraries," a recently funded N.C. Humanities project, and discussion and development of the group's 1983 legislative goals and objectives.

The annual Public Service Award was presented to Senator Harold W. Hardison and Representative Al Adams. Both Senator Hardison and Representative Adams have demonstrated continued support for libraries at the local and state levels. The award recognizes non-librarian contributions to public libraries.

Senator Hardison provided the leadership that secured over $\$ 2,000,000.00$ in additional State Aid for construction of public libraries.
Because of his efforts to date fifteen new and remodeled public libraries are completed, under construction or in the planning stage. During the past two years Senator Hardison has introduced legislation providing over $\$ 800,000.00$ in additional operational revenue for the state's public libraries.

Representative Adams' service to public libraries goes back to 1964 when he served on the organization committee for North Carolinians for Better Libraries. He was a leader in organizing Wake County citizens in the fifteenyear program to secure better library facilities. He served on the Wake County Board of Trustees from 1969 to 1978 and as its chairman from 1972 to 1976 . As a legislator he has been a member of the House Library Committee and a strong supporter of library aid in the General Assembly.

The following will serve as officers of the Association for the coming year: Nancy Massey, President; Jerry Thrasher, VicePresident/President elect; Dale Gaddis, Secretary; Lib Laney, Treasurer; Barbara Johnson, County Library Representative; Ed Sheary, Regional Library Representative; and Robert Russell, Municipal Library Representative.

\section{Microcomputer Users Group Formed}

Following two successful workshops on microcomputers in libraries, the Microcomputer Users Group for Libraries in North Carolina has been formed. The primary purpose of the group is to promote the understanding and use of microcomputers in libraries throughout North Carolina.

Among its planned services are a quarterly newsletter which will be sent to all members, a resource directory of hardware and software applications in North Carolina libraries, a beginners workshop in April or May, a workshop on database management in April or May, and a summer computer camp for librarians, to be held at the School of Science and Mathe. matics in August.

Annual membership in the Microcomputer Users Group is only $\$ 5.00$ and may be sent to the Group's treasurer, Robert Burgin, c/o Forsyth County Public Library, 660 West Fifth Street. Winston-Salem, North Carolina 27101. 